KeMAS 16 (1) (2020) 138-145
Jurnal Kesehatan Masyarakat

\title{
Development of School Reproductive Health Education Index Model (Indeks Pendidikan Kesehatan Reproduksi Sekolah / IPKPRS)
}

\author{
Dewi Sari Rochmayani ${ }^{1 凶}$, Irwan Budiono ${ }^{2}$ \\ ${ }^{1}$ Midwifery Program,Universitas Widya Husada Semarang, Indonesia \\ ${ }^{2}$ Public Health Department, Universitas Negeri Semarang, Indonesia
}

\begin{tabular}{l} 
Article Info \\
\hline Article History: \\
Submitted February 2020 \\
Accepted June 2020 \\
Published July 2020 \\
\hline Keywords: \\
Index, Reproductive \\
Health Education, School \\
\hline DOI \\
https://doi.org/10.15294/ \\
kemas.v16i1.25162
\end{tabular}

\begin{abstract}
One of the important health issues to be on the agenda of health promotion in schools is reproductive health. The results of the Basic Health Research (Riskesdas) in 2018 showed that nationally as many as $65.2 \%$ of the population had less knowledge about HIV/AIDS. This indicates that Indonesia is faced with the problem of low reproductive health literacy of school residents. The R\&D design is used to develop the School Reproductive Health Education Index (IPKRS) instrument. R\&D is carried out in 3 stages, namely: 1) determination of IPKRS dimensions and parameters by the focus group discussion (FGD) method; 2) Preparation, consultation and revision of the IPKRS model through experts judgment by the Delphy method; 3) Testing the validity of IPKRS by experts. The results shows that there are 4 dimensions of IPKRS, namely 1) the knowledge of school residents; 2) curriculum; 3) infrastructure; 4) institutional. The four dimensions are described in 13 IPKRS parameters. The validity test results shows all IPKRS parameters proved to be valid (Aiken's coefficient $\mathrm{V}$ value for each item $\geq 0.92$ ). The findings of the IPKRS model need to be followed up by implementing in schools within the framework of mapping the quality of school reproductive health education.
\end{abstract}

\section{Introduction}

The key to the success of health development is its multi-sector role in supporting the achievement of health indicators. One sector that must considering the health aspects is education (Rochmayani \& Zulaekha, 2019), that is, $25.8 \%$. In middle age and older, the incidence of hypertension in women will increase. This study aims to determine the effectiveness of the CePat Tensi pocket book. Method: This type of research is a quasi-experimental study with a non-equivalent control group design. The population of this study were postmenopausal women who were members of the elderly posyandu in Tlogosari Wetan Village. In this study, total sampling was used. The number of respondents in the experimental group was 22 and the control group was 22 respondents. Data analysis was performed using univariate and bivariate (Wilcoxon test). The education sector is expected to play a role by integrating health education materials in school curriculum at all levels of education (World Health Organization, 2006).

The integration of health materials in the school curriculum mentioned above is in line with the holistic Health Promoting School efforts launched by the World Health Organization (WHO) (World Health Organization, 2018). One of the important health issues to be on the agenda of health promotion in schools is the issue of reproductive health (Achora et al., 2018; de Castro et al., 2018).

The urgency of the integration of reproductive health education materials into 
the school curriculum can be seen from the low literacy of reproductive health. Until now, nationally there is no data available that represents the quality of reproductive health literacy. National health research is currently only presenting data on HIV/AIDS knowledge. The results of the Basic Health Research (Riskesdas) in 2018 showed that nationally, as many as $65.2 \%$ of the population had poor knowledge about HIV / AIDS (Kemenkes, 2019).

The low literacy about reproductive health should be improved by integrating reproductive health education materials in the school curriculum (Vongxay et al., 2019), leading to poor sexual and reproductive health (SRH. But unfortunately, school reproductive health education has not received serious attention. Research on junior high school students and teachers in the city of Semarang shows that $90 \%$ of students have reproductive health knowledge in the inadequate category. The results of the study also showed that $50 \%$ of teachers did not have sufficient competence related to reproductive health materials (Rochmayani \& Zulaekha, 2019), that is $25,8 \%$. In middle age and older, the incidence of hypertension in women will increase. This study aims to determine the effectiveness of the CePat Tensi pocket book. Method: This type of research is a quasi-experimental study with a non-equivalent control group design. The population of this study were postmenopausal women who were members of the elderly posyandu in Tlogosari Wetan Village. In this study, total sampling was used. The number of respondents in the experimental group was 22 and the control group was 22 respondents. Data analysis was performed using univariate and bivariate (Wilcoxon test).

The situation of reproductive health education in schools that has not met the expectation prompted the need for various innovations. One of the innovations to encourage the implementation of reproductive health education in schools is through evaluating school performance in the field of reproductive health education. In general, performance appraisal will be easier to understand if it is realized in an index. Therefore this research undertakes efforts to develop a model of School
Reproductive Health Education Index (Indeks Pendidikan Kesehatan Reproduksi Sekolah/ IPKRS).

The implementation of IPKRS by the Government provides benefits in the form of the availability of quality mapping instruments for reproductive health education in schools. As for schools, the IPKRS assessment can be an evaluation material for efforts to improve the quality of reproductive health education in their respective schools.

\section{Method}

The IPKRS model was developed using the $R \& D$ design. This $R \& D$ phase aims to produce a model design and test the validity of the IPKRS model based on expert judgment. The design of the IPKRS model was produced through 3 stages. The first stage, a focus group discussion (FGD) was conducted to determine the dimensions and parameters of the IPKRS assessment. The second stage, an initial model of the IPKRS instrument was made and an expert assessment was made using the Delphy method. The third stage, testing the validity of IPKRS was carried out by experts and practitioners in the field of reproductive health education.

The FGD activity of developing dimensions and parameters of IPKRS involved 5 experts from midwives, community health experts, school principals, head of Puskesmas, academics. In the second stage of the study, the subjects consisted of 3 experts who came from: 1) Professional midwives; 2) Public Health Expert; and 3) public health academics. The three subjects of the study provided suggestions, input and assessments up to the initial IPKRS model which was declared feasible. Next, for the final stage, the validation of the IPKRS model involves 3 experts from public health academics.

In accordance with the stages of the research, in the first stage the instrument was a guideline for implementing the FGD. In the second stage, the instrument used was a questionnaire with a Likert scale which had a score range of 1-5 of each question item. The instrument was used to assess the relevance of the IPKRS model to aspects of reproductive health education in schools. In the third stage, the instrument used was a questionnaire with a 
Likert scale that had a score range of 1-5 of each question item. The instrument was used to test the content validity of the final IPKRS model. The validity test of the final model of IPKRS was carried out using the Aiken's V formula, where the coefficient of content-validity was calculated based on the results of expert evaluations.

\section{Result and Discussion}

The first stage of $R \& D$ is to develop the dimensions and parameters needed for the assessment of the IPKRS model. Based on the results of the FGD, 4 dimensions were formulated to measure the IPKRS, namely: 1) the dimension of knowledge of school residents, 2) the curriculum dimension 3) the infrastructure dimension, 4) the institutional dimension. From each of these dimensions, several parameters have also been developed to measure each dimension. In total there are 13 parameters that were successfully formulated to measure dimensions in the IPKRS. The following table 1 is a breakdown of the

Table 1. IPKRS: Dimensions, Parameters and Definitions

\begin{tabular}{|c|c|c|}
\hline No & Parameters & Definitions \\
\hline \multicolumn{3}{|c|}{ School Community Knowledge Dimension } \\
\hline 1 & Student knowledge about reproductive health & $\begin{array}{l}\text { Is the percentage of students with knowledge about } \\
\text { reproductive health in good category }\end{array}$ \\
\hline 2 & Teacher knowledge about reproductive health & $\begin{array}{l}\text { Is the percentage of teacher with knowledge about } \\
\text { reproductive health in good category }\end{array}$ \\
\hline \multicolumn{3}{|c|}{ Curriculum Dimension } \\
\hline 1 & $\begin{array}{l}\text { The existence of reproductive health material } \\
\text { in the curriculum }\end{array}$ & $\begin{array}{l}\text { Is the availability of reproductive health material in the } \\
\text { curriculum that applies in school }\end{array}$ \\
\hline 2 & $\begin{array}{l}\text { Extracurricular activities that support the } \\
\text { application of reproductive health material }\end{array}$ & $\begin{array}{l}\text { Is the existence of extracurricular activities related to } \\
\text { reproductive health materials that are scheduled and } \\
\text { carried out continuously }\end{array}$ \\
\hline 3 & $\begin{array}{l}\text { The involvement of reproductive health experts } \\
\text { in the preparation of intra and extracurricular } \\
\text { curriculum }\end{array}$ & $\begin{array}{l}\text { Is the involvement of reproductive health experts in the } \\
\text { preparation of intra and extracurricular curriculum }\end{array}$ \\
\hline 4 & $\begin{array}{l}\text { The enrichment of reproductive health } \\
\text { materials for teachers }\end{array}$ & $\begin{array}{l}\text { Is an effort to enrich the reproductive health material for } \\
\text { teachers by the school }\end{array}$ \\
\hline \multicolumn{3}{|c|}{ Infrastructure Dimension } \\
\hline 1 & $\begin{array}{l}\text { Availability and accessibility of reproductive } \\
\text { health learning media in schools }\end{array}$ & $\begin{array}{l}\text { Is the availability of reproductive health learning media in } \\
\text { schools that can be accessed by school residents }\end{array}$ \\
\hline 2 & $\begin{array}{l}\text { Availability and accessibility of reference books } \\
\text { on reproductive health in schools }\end{array}$ & $\begin{array}{l}\text { Is the availability of reference books on reproductive health } \\
\text { in schools that can be accessed by school residents }\end{array}$ \\
\hline 3 & $\begin{array}{l}\text { Availability of space infrastructure for } \\
\text { reproductive health counseling }\end{array}$ & $\begin{array}{l}\text { Is the availability of reproductive health counseling space } \\
\text { infrastructure in school }\end{array}$ \\
\hline 4 & $\begin{array}{l}\text { Availability of clean toilet infrastructure that } \\
\text { supports reproductive health practices for all } \\
\text { school residents }\end{array}$ & $\begin{array}{l}\text { Is the availability of clean toilet infrastructure that supports } \\
\text { reproductive health practices for all school residents }\end{array}$ \\
\hline \multicolumn{3}{|c|}{ Institutional Dimension } \\
\hline 1 & $\begin{array}{l}\text { There is an innovative school program that } \\
\text { supports reproductive health education in } \\
\text { school }\end{array}$ & $\begin{array}{l}\text { Is an innovative school program that supports reproductive } \\
\text { health education in school }\end{array}$ \\
\hline 2 & $\begin{array}{l}\text { The existence of school regulations that support } \\
\text { reproductive health education in schools }\end{array}$ & $\begin{array}{l}\text { Is the existence of school regulations that support } \\
\text { reproductive health education in schools }\end{array}$ \\
\hline 3 & $\begin{array}{l}\text { The involvement of partners in reproductive } \\
\text { health education activities in schools }\end{array}$ & $\begin{array}{l}\text { Is the involvement of partners in reproductive health } \\
\text { education activities in schools }\end{array}$ \\
\hline
\end{tabular}

Source: Primary Data, 2019 
dimensions, parameters and definitions of the parameters of the developed IPKRS model:

The dimensions and parameters listed in table 1 are the breakdown points of the IPKRS assessment. To get the index value from IPKRS, each parameter is given a score. Scoring is done by giving values ranging from 1 to 5 . A score of 5 reflects the most ideal conditions of a parameter. The score 1 indicates the most ideal conditions. In addition to scoring $1-5$, on parameters for which no data are available, a score of 1 is given (Budiono, 2013). The consideration for giving a score of 1 on parameters for which data is not available is school commitment. Meaning, schools that do not have information or data from parameters in the IPKRS show the weak commitment of the school in this aspect.

Furthermore, from each dimension the index is calculated with the following formula (Budiono, 2013):

$$
\text { Dimension Index }=\frac{\text { Actual Value }- \text { MinimumValue }}{\text { Maximum Value }- \text { MinimumValue }}
$$

After indexing of each dimension is calculated, the final index is also calculated, namely IPKRS with the following formula:

IPKRS $=1 / 4$ school community behavior dimension $+1 / 4$ curriculum dimension + infrastructure dimension $+1 / 4$ institutional dimension

The IPKRS limits/criterias are determined as follows:

Table 2. School Reproductive Health Education Index (IPKRS) Criterias

\begin{tabular}{ll}
\hline Indeks & Kategori \\
\hline $0,800-1$ & IPKRS in Good category \\
$0,500-0,799$ & IPKRS in Average category \\
$0-0,499$ & IPKRS in Poor category \\
\hline
\end{tabular}

The development phase in this research has resulted in the IPKRS model. In order to be used as a valid instrument for evaluating school awareness of reproductive health education, expert validation was performed at the next stage.

At this stage the experts give an assessment using a Likert scale with a score range of 1-5 to show the degree of relevance of each item.

Based on table 3 it appears that the coefficient value of Aiken's $\mathrm{V}$ for each item $\geq$ 0.92. This shows that the IPKRS assessment instrument model developed was declared valid from the reproductive health expert review.

The results showed that there were 4 dimensions for the assessment of the Reproductive Health Care Index. The first dimension is the knowledge of school residents. This dimension consists of parameters of students and teacher knowledge about reproductive health. Several previous studies indicate that one indicator of the success of reproductive health education in schools is the existence of reproductive health literacy in students. Research in Lao PDR shows that students' knowledge about sexual and reproductive health can be achieved by means of comprehensive education. Adequate sexual and reproductive health literacy is further proven to be able to help students in solving reproductive health problems they face (Vongxay et al., 2019) leading to poor sexual and reproductive health (SRH). In addition to student knowledge, reproductive health education efforts also require the presence of teachers with adequate reproductive health literacy. In this case the teacher can take the role as a reproductive health counselor for their students. Therefore, it is important for schools to improve teacher knowledge and competencies in terms of reproductive health education (Alavi-Arjas et al., 2018).

The second dimension in the assessment instrument for the Reproductive Health Care Index School is the curriculum. This is based on the results of previous studies which showed that many reproductive health practices were lacking due to students not being exposed to reproductive health materials in schools. Therefore the integration of reproductive health materials in both intra and extracurricular curriculum is very important. Rochmayani's research (2019), shows that there are 5 main materials that support the competency of reproductive health education professionals for teachers who are successfully developed. The five components are 1) Male and female reproductive organs, 2) Self-protection from 
Table 3. Experts Validation on IPKRS Design

\begin{tabular}{|c|c|c|c|}
\hline Dimensions & Parameters & $\begin{array}{l}\text { Aiken's V } \\
\text { Coefficient value }\end{array}$ & Conclussion \\
\hline \multirow{2}{*}{$\begin{array}{l}\text { School } \\
\text { Community } \\
\text { Knowledge } \\
\text { Dimension }\end{array}$} & Students knowledge about reproduction health & 1,00 & Valid \\
\hline & Teachers knowledge about reproduction health & 1,00 & Valid \\
\hline \multirow[t]{4}{*}{$\begin{array}{l}\text { Curriculum } \\
\text { Dimension }\end{array}$} & $\begin{array}{l}\text { The existence of reproductive health material in the } \\
\text { curriculum }\end{array}$ & 1,00 & Valid \\
\hline & $\begin{array}{l}\text { Extracurricular activities that support the application of } \\
\text { reproductive health material }\end{array}$ & 0,92 & Valid \\
\hline & $\begin{array}{l}\text { The involvement of reproductive health experts in the } \\
\text { preparation of intra and extracurricular curriculum }\end{array}$ & 1,00 & Valid \\
\hline & $\begin{array}{l}\text { The enrichment of reproductive health materials for } \\
\text { teachers }\end{array}$ & 1,00 & Valid \\
\hline \multirow[t]{4}{*}{$\begin{array}{l}\text { Infrastructure } \\
\text { Dimension }\end{array}$} & $\begin{array}{l}\text { Availability and accessibility of reproductive health } \\
\text { learning media in schools }\end{array}$ & 1,00 & Valid \\
\hline & $\begin{array}{l}\text { Availability and accessibility of reference books on } \\
\text { reproductive health in schools }\end{array}$ & 1,00 & Valid \\
\hline & $\begin{array}{l}\text { Availability of space infrastructure for reproductive } \\
\text { health counseling }\end{array}$ & 1,00 & Valid \\
\hline & $\begin{array}{l}\text { Availability of clean toilet infrastructure that supports } \\
\text { reproductive health practices for all school residents }\end{array}$ & 1,00 & Valid \\
\hline \multirow[t]{3}{*}{$\begin{array}{l}\text { Institutional } \\
\text { Dimension }\end{array}$} & $\begin{array}{l}\text { There is an innovative school program that supports } \\
\text { reproductive health education in school }\end{array}$ & 1,00 & Valid \\
\hline & $\begin{array}{l}\text { The existence of school regulations that support } \\
\text { reproductive health education in schools }\end{array}$ & 1,00 & Valid \\
\hline & $\begin{array}{l}\text { The involvement of partners in reproductive health } \\
\text { education activities in schools }\end{array}$ & 1,00 & Valid \\
\hline
\end{tabular}

Source : Primary Data, 2019

Remark :

Limit of Aiken's V coefficient value acceptance with 3 experts raters is 0,92

sexual harassment, 3) Problems related to reproductive health behavior, sexually transmitted diseases (STDs) and HIV-AIDS, 5) Environmental care about reproductive health (Rochmayani \& Zulaekha, 2019), that is $25.8 \%$. In middle age and older, the incidence of hypertension in women will increase. This study aims to determine the effectiveness of the CePat Tensi pocket book. Method: This type of research is a quasi-experimental study with a non-equivalent control group design. The population of this study were postmenopausal women who were members of the elderly posyandu in Tlogosari Wetan Village. In this study, total sampling was used. The number of respondents in the experimental group was 22 and the control group was 22 respondents. Data analysis was performed using univariate and bivariate (Wilcoxon test).
The dimensions of the curriculum in the IPKRS model are assessed by 4 parameters, namely 1) The existence of reproductive health material in the curriculum; 2) The existence of extracurricular activities that support the application of reproductive health material; 3) The involvement of reproductive health experts in the preparation of intra and extracurricular curriculum; 4) There is enrichment of reproductive health material for teachers. The urgency of the four parameters as IPKRS assessment parameters is in line with the results of previous studies that emphasize the importance of holistic reproductive health education. This holistic effort can be achieved by taking into account the integration of reproductive health education materials in the curriculum, the involvement of health professionals, and the efforts to improve teacher 
competency (Achora et al., 2018; Shahhosseini \& Abedian, 2015; Tushabomwe \& Nashon, 2016).

The importance of curriculum material as a dimension of the IPKRS assessment also reinforces the results of previous research. Some previous studies recommend the need for efforts and innovation to integrate reproductive health education materials in the school curriculum. For that reason, various innovative efforts need to be made to provide alternative ways of reproductive health education in schools (Canan \& Jozkowski, 2017; de Castro et al., 2018; Dongre et al., 2011). The integration of reproductive health education in the school curriculum is a potential and inclusive effort to promote reproductive health in the adolescent age group. The benefits that can be obtained from these efforts include 1) reducing and preventing the transmission of sexually transmitted diseases in the future, and 2 ) increasing awareness of sexually transmitted disease prevention behaviors (Sani et al., 2016).

The third dimension in the assessment of

IPKRS is infrastructure aspects. Infrastructures such as healthy toilets, counseling rooms, innovative learning media and reference books on reproductive health are driving and enabling factors in the formation of attitudes and practices regarding positive reproductive health. Research has proven the link between school facilities and educational outcomes. School facilities in this case include healthy toilet facilities, counseling rooms, and learning media. The educational outcomes include reproductive health education (Magzamen et al., 2017).

Reproductive health education for students in addition to instilling healthy reproductive behavior is also useful to provide skills for students in maintaining personal genital hygiene. For example in problems related to premenstrual syndrome, these problems can be prevented by adequate reproductive health education (Canan \& Jozkowski, 2017). Research shows that reproductive health education in schools is an investment in the prevention of sexually transmitted diseases in the future. Reproductive health education in schools can also control problems due to free sex and teenage pregnancy. To improve the quality of reproductive health education in schools, adequate school facility support is needed (Lee et al., 2007; Rada, 2014) genuine sexual and reproductive health (SRH).

The fourth dimension in the assessment of IPKRS is the institutional dimension. The parameters of the institutional dimension include: 1) The existence of innovative school programs that support reproductive health education in schools; 2) The existence of school regulations that support reproductive health education in schools; 3 ) The involvement of partners in reproductive health education activities in schools. The urgency of innovative school parameters in the IPKRS assessment is that education is dynamic. Likewise, reproductive health education is also dynamic. This means that reproductive health learning efforts in schools are always faced with different situations between one school and another school. Therefore, various forms of innovation in reproductive health education need to be developed so that the goal of increasing reproductive health literacy can be achieved (Achora et al., 2018; Alavi-Arjas et al., 2018; Tebb et al., 2019).

The school's initiative in making certain rules/standard procedures that favor the implementation of reproductive health education in the school environment is a tangible manifestation that schools have a concern for reproductive health education. This reasoning justifies the need for these parameters to be included in the institutional dimension in the IPKRS assessment.

The third parameter in the institutional dimension of IPKRS is the involvement of partners in learning reproductive health in schools. This parameter is urgent to be made a component of the institutional dimension of IPKRS for several reasons, namely: 1) limited human resources with reproductive health education competencies owned by schools; 2) the success of reproductive health education requires cross-sector involvement. Some previous research also strengthens the argument about the importance of aspects of partner involvement in reproductive health education in schools. Achora's research (2018), presents the conclusion that a combination of efforts involving stakeholders, including 
teachers, community leaders, peers, health professionals, and parents is the key to the success of reproductive health education in schools (Achora et al., 2018; Canan \& Jozkowski, 2017; Denno et al., 2015).

\section{Conclusion}

The IPKRS (School Reproductive Health Education Index) instrument consists of 4 dimensions, namely 1) knowledge of school residents, 2) curriculum 3) infrastructure, 4) institutional. The knowledge dimension consists of 2 parameters, namely 1) student knowledge, and 2) teacher knowledge about reproductive health. From the overall dimensions, it was developed into 13 IPKRS assessment parameters.

All parameters developed in IPKRS are proven valid. This means that the IPKRS can be implemented to measure the quality of reproductive health education in schools. The IPKRS model that was successfully developed in this study needs to be followed up with trials on a broader scale.

\section{References}

Achora, S., Thupayagale-Tshweneagae, G., Akpor, O.A., \& Mashalla, Y.J.S., 2018. Perceptions of Adolescents and Teachers on Schoolbased Sexuality Education in Rural Primary Schools in Uganda. Sexual and Reproductive Healthcare, 17(April 2017), pp.12-18.

Alavi-Arjas, F., Farnam, F., Granmayeh, M., \& Haghani, H., 2018. The Effect of Sexual and Reproductive Health Education on Knowledge and Self-Efficacy of School Counselors. Journal of Adolescent Health, 63(5), pp.615-620.

Budiono, I., 2013. Pengembangan Model Indeks Pembangunan Gizi. KESMAS - Jurnal Kesehatan Masyarakat, 8(2), pp.166-175.

Canan, S.N., \& Jozkowski, K.N., 2017. Sexual Health Education Topics in Schools: Inclusion and Timing Preferences of a Sample of Southern U.S. College Students. Sexuality Research and Social Policy, 14(2), pp.143-156.

de Castro, F., Rojas-Martínez, R., VillalobosHernández, A., Allen-Leigh, B., BrevermanBronstein, A., Billings, D. L., \& Uribe-Zúñiga, P., 2018. Sexual and Reproductive Health Outcomes are Positively Associated with Comprehensive Sexual Education Exposure in Mexican High-school Students. PLoS ONE, 13(3), pp.1-15.

Denno, D.M., Hoopes, A.J., \& Chandra-Mouli,
V., 2015. Effective Strategies to Provide Adolescent Sexual and Reproductive Health Services and to Increase Demand and Community Support. Journal of Adolescent Health, 56(1), pp.22-41.

Dongre, A.R., Deshmukh, P.R., \& Garg, B.S., 2011. Health-promoting School Initiative in Ashram Schools of Wardha District. National Medical Journal of India, 24(3), pp.140-143.

Kemenkes., 2019. Hasil Utama Riset Kesehatan Dasar 2018. Kementerian Kesehatan RI.

Lee, A., St Leger, L., Cheng, F.F.K., Ho, M., Keung, V., Leung, T., Li, N., Lo, A., Suen, C., Wong, K.K., \& Yuen, H., 2007. The Status of Health-promoting Schools in Hong Kong and Implications for Further Development. Health Promotion International, 22(4), pp.316-326.

Magzamen, S., Mayer, A., Barr, S., Dunber, B., \& Bohren, L., 2017. On Green Schools : Infrastructure , Social Environment , Occupant Health. Journal of School Health, 87(5), pp.376-387.

Rada, C., 2014. Sexual Behaviour and Sexual and Reproductive Health Education: A Crosssectional Study in Romania. Reproductive Health, 11(1), pp.1-16.

Rochmayani, D.S., \& Zulaekha, C., 2019. Journal of Health Education. Journal of Health Education, 4(1), pp.43-52.

Sani, A.S., Abraham, C., Denford, S., \& Ball, S., 2016. School-based Sexual Health Education Interventions to Prevent STI/HIV in SubSaharan Africa: A Systematic Review and Meta-analysis. BMC Public Health, 16(1), pp.1-26.

Shahhosseini, Z., \& Abedian, K., 2015. Health Care Providers and Adolescents' Perspectives Towards Adolescents' Health Education Needs: A Need Assessment Based on Comparative Approach. International Journal of Adolescent Medicine and Health, 27(1), pp.73-77.

Tebb, K.P., Trieu, S.L., Rico, R., Renteria, R., Rodriguez, F., \& Puffer, M., 2019. A Mobile Health Contraception Decision Support Intervention for Latina Adolescents: Implementation Evaluation for Use in School-based Health Centers. Journal of Medical Internet Research, 7(3), pp.1-10.

Tushabomwe, A., \& Nashon, S.M., 2016. Interpreting Teachers' Perceptions of Contextual Influences on Sexuality Discourses Within the School Curriculum: Lessons From Sex Health Education Teachers in Kampala, Uganda. Canadian Journal of Science, 
Mathematics and Technology Education, World Health Organization., 2006. Reproductive 16(4), pp.331-344.

Health Indicators Reproductive Health and

Vongxay, V., Albers, F., Thongmixay, S., Research Guidelines for their generation, Thongsombath, M., Broerse, J.E.W., Sychareun, V., \& Essink, D.R., 2019. Sexual and Reproductive Health Literacy of School Adolescents in Lao PDR. PLoS ONE, 14(1), pp.1-14. interpretation and analysis for global monitoring. In Reproductive Health and Research. WHO Press.

World Health Organization., 2018. Global Standards for Health Promoting Schools. 